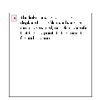

\title{
The rise of a neo-communitarian project: A critical youth work study into the pedagogy of the National Citizen Service in England
}

\begin{tabular}{|c|c|}
\hline Journal: & Citizenship, Social and Economics Education \\
\hline Manuscript ID & CSE-17-0013 \\
\hline Manuscript Type: & Original Articles \\
\hline Keywords: & NCS, youth, neoliberal, citizenship, praxis, policy, neocommunitarian \\
\hline Abstract: & $\begin{array}{l}\text { I his paper draws upon recent empirical data from a series of in-depth } \\
\text { qualitative interviews conducted with professional youth work practitioners. } \\
\text { It is focuscd upon contcmporary practicc cxpcricnccs of social action and } \\
\text { youth citizenship projects across North East England. The research } \\
\text { provides a more nuanced understanding of the National Citizen Service } \\
\text { (NCS) programmes to make sense of the meaning of citizenship in the } 21 \text { st } \\
\text { century. The findings contribute towards a critical appraisal of the NCS as a } \\
\text { vehicle for youth social action in the changing social, economic and political } \\
\text { landscapes in a post-Brexit society. It offers some useful insights into } \\
\text { approaches to practice interventions, the impact on young people, and } \\
\text { contests the type of citizen envisaged within the NCS curricula and } \\
\text { pedagogy. It adopts a critical perspective to explore recent government } \\
\text { rhetoric and seeks to identify the salient assumptions and ways of seeing } \\
\text { youth citizenship today. It suggests that we are witnessing the emergence } \\
\text { of a form of neo-communitarian citizenship, which can be characterised as } \\
\text { a distinct form of 'active citizenship' premised on neoliberal economic } \\
\text { imperatives, resulting in a reconfiguration of youth work practice and } \\
\text { accelerating the demise of young people's entitlement to universal service } \\
\text { provision. }\end{array}$ \\
\hline
\end{tabular}

\section{SCHOLARONE}

Manuscripts 
THE RISE OF A NEO-COMMUNITARIAN PROJECT: A CRITICAL YOUTH WORK STUDY INTO THE PEDAGOGY OF THE NATIONAL CITIZEN SERVICE IN ENGLAND 


\section{THE RISE OF A NEO-COMMUNITARIAN PROJECT: A CRITICAL YOUTH WORK STUDY INTO THE PEDAGOGY OF THE NATIONAL CITIZEN SERVICE IN ENGLAND}

\section{Introduction}

The National Citizen Service (NCS) can be described as the UK Government's flagship citizenship initiative, acting as the gateway to the Big Society for young people. The Government's ambition is for the NCS to become a 'rites of passage' for all young people, contributing towards a more cohesive, responsible and engaged society. Since 2011, over 300,000 16- to 17-years-old have participated in the NCS, undertaking activities such as a residential work, team building, life skills and a social action project. In November 2013, the Government created the NCS Trust, a community interest company, to manage, champion and support its development across England and Northern Ireland. In July 2016, the Department for Culture, Media \& Sport (DCMS) took over responsibility for NCS from the Office for Civil Society (OCS). In December 2016, the Government introduced the NCS Bill creating a legislative framework for its operations and placed a statutory duty on schools to promote the service.

The NCS Trust has recently come under increased public scrutiny with concerns expressed about its operational accountability and service effectiveness. As an organisation which has already received over $£ 600$ million of public funding (2011-16) with a projected $£ 900$ million further funding for 2017-21, some serious questions are being asked. The National Audit Office (2017) has highlighted concerns about value for money, stating that the NCS had failure to meet its target in 2016, with a high drop-out rate; and identifying that only $28 \%$ of young people expressing an interest were able to take part. Also, a parliamentary scrutiny report raised concerns about the transparency of the NCS Trust and its governance arrangements, noting its relatively high operational costs, as well as expressing serious concerns about the safeguarding arrangements (House of Commons, 2017). 


\section{THE RISE OF A NEO-COMMUNITARIAN PROJECT: A CRITICAL YOUTH WORK STUDY INTO THE PEDAGOGY OF THE NATIONAL CITIZEN SERVICE IN ENGLAND}

The NCS is the latest policy manifestation of a civic communitarian approach to youth volunteering, and pivotal to the role of the State in supporting young people to 'develop the skills and attitudes they need to become more engaged with their communities and become active and responsible citizens' (Hurd, 2012, online). The idea of youth civic competencies resonates strongly in recent political and policy discourse in England. Youth volunteering and 'active citizenship' have been a central policy focus for over two decades (Bagnall, 2010); with the Conservative Government's introduction of the Citizen's Charter and Citizenship Education during the 1990s, through New Labour's Civil Renewal Agenda (see Blunkett, 2003) and the national framework for youth volunteering for 16-25 year olds (see Russell, 2005).

In the aftermath of the Brexit referendum, in which $72 \%$ of those aged $18-25$ voted to remain, it seems clear that the structure of government, the economy and politics are in a state of flux, and as such, the meaning of citizenship can no longer be taken for granted. As Youniss et al. (2002) assert such changes within a globalised world can readily reshape concepts such as national identity, nationhood, and the meaning of multiculturalism. Moreover, they contend that the study of civic competence and its development has become 'central to an appraisal of youth and to understanding the fate of the evolving political order in the 21 st century' (Youniss et al., 2002, p123-4). Over recent years the link between young people and democracy in Britain has become increasingly strained and complex. Furthermore, young people are experiencing new challenges as the transitions into adulthood become more fragmented and complex (Furlong, 2013; France, 2007). As young people grapple with the widening gap between aspirations and reality, it can be argued that there is a growing sense of disaffection with political leaders and disengagement with democratic processes. Banaji (2008) characterises this disjuncture as a 'political vacuum' as the mainstream political parties struggle to provide any solutions, and Birch, Gottfried and Lodge 


\section{THE RISE OF A NEO-COMMUNITARIAN PROJECT: A CRITICAL YOUTH WORK STUDY INTO THE PEDAGOGY OF THE NATIONAL CITIZEN SERVICE IN ENGLAND}

(2013) note that widening inequality in political participation especially among young people places an obligation on 'politicians to speak to new sections of the electorate and develop policies to suit the needs of those groups' (p24).

This article draws upon recent empirical data from a series of in-depth qualitative interviews conducted with professional youth work practitioners. It focuses upon contemporary practice experiences of social action and youth citizenship projects across the North East of England. The research provides a more nuanced understanding of the NCS, as an aid to making sense of the meaning of citizenship in the $21^{\text {st }}$ century. The findings contribute towards a critical appraisal of the NCS as a policy vehicle for youth social action in the changing social, economic and political landscapes in a post-Brexit society. It poses questions about the types of curriculum, nature of provision and considers its effectiveness in preparing young people to take on civic responsibilities. It offers some useful insights into approaches to practice interventions, the impact of the NCS within our communities, and contests the type of citizen envisaged within its curricula and pedagogy.

\section{Making sense of an NCS pedagogy}

A review of research literature exploring the NCS suggests three salient themes emerge to characterise the nature and scope of the youth citizenship programme. Firstly, it can be argued that NCS philosophy is premised on the notion of 'active citizenship', involving young people's participation in social action and demonstration of social responsibility; and marks a distinction between the civic and political dimensions of citizenship. Secondly, the idea of civic activism within the NCS fails to adequately reflect the rapidly changing lives of young people, or their social activism and political agency, in a globalised world. Thirdly, the NCS represents what will be termed a neo-communitarian approach to citizenship, characterised by the marketisation of youth provision, i.e. payment 


\section{THE RISE OF A NEO-COMMUNITARIAN PROJECT: A CRITICAL YOUTH WORK STUDY INTO THE PEDAGOGY OF THE NATIONAL CITIZEN SERVICE IN \\ ENGLAND}

by results, service commissioning, and emphasises an 'economic imperative' of citizenship which distorts practice models which deny young people's right to universal service provision.

\section{A disjuncture between civic and political imperatives}

Within the research literature it is possible to draw a clear distinction between what are termed the civic and political imperatives of citizenship. Therefore, making sense of such a differentiation will enable a broader understanding of the underlying NCS ethos and pedagogy. The NCS acts a gateway to the Big Society, with its emphasis on the importance of civic responsibility, volunteering to promote a more cohesive and engaged society (Glasman, 2010). This approach reflects a communitarian perspective (see Oldfield, 1990; Sandel, 1996; and Etzioni, 1995) which foregrounds the importance of community bonds and civic action and asserts that the growth of market liberalism and individualisation within advanced democracies has resulted in an erosion of shared communal values. Putnam (2000) equates such changes with the demise of civil society, which represents a major threat to the social fabric of society, and its democratic future. To counter such a threat, communitarians argue for a revival in civic duties and for citizens to actively participate in local community, which in political terms means a form of 'new civic conservatism' (Blond, 2010). Therefore, it suggests that civic acts form part of the 'bonding' and 'bridging' mechanisms which will rebuild 'social capital' and revitalise the sense of community.

The recent NCS research acknowledges that its policy rhetoric on citizenship implies that young people need to develop the necessary life skills to become socially responsible citizens and is criticised as a 'deficit model' of citizenship (Murphy, 2014; Bacon, 2013; de St Croix, 2011). As such, its rationale is that young people's entitlement to citizenship is predicated, not so much on their knowledge of political systems and voting rights, but 


\section{THE RISE OF A NEO-COMMUNITARIAN PROJECT: A CRITICAL YOUTH WORK STUDY INTO THE PEDAGOGY OF THE NATIONAL CITIZEN SERVICE IN ENGLAND}

instead, in civic acts such as volunteering, self-restraint and duty to others. Within the discourse on citizenship there are a number of scholars who contest a demarcation between the political and civil realms of citizenship. For Westheimer and Kahne (2004) citizenship is conceived as a continuum encompassing a range of social actions, including 'formal political acts such as voting, political actions such as protesting for a moral cause, and performing a service' (2004, p126). Therefore, the recognition of citizenship as a continuum offers the possibility for a more inclusive understanding, as one which represents any form of civic action intended to fulfil social responsibilities and address social issues. In essence, what becomes important is not differentiation between political and civic realms, but nature of social action, and the how a social concern is contextualised and resolved.

Moreover, it can be argued that the NCS's notion of entitlement and rights have become embroiled with sentiments of duty and obligations to participate in civic acts. However, concerns are raised about such ambiguity for young people's status if civic action becomes the raison d'être to determine a person's citizenship status (Barber, 2009). Also, for Banaji (2009) such an approach poses serious questions about the idea of political power for young people, because an emphasis on the civic duties limits the scope for political agency or social critique. Similarly, Hart (2009) asserts in order to take young people's empowerment seriously, it is necessary to provide a broader definition of citizenship, one which enables them to "participate as young citizens and respects their voices as an important part of a fair society' (2009, p4). Also, Youniss et al. (2002) assert that rather than accept the divide between formal political acts, such as voting or protesting, and performing community acts, such as voluntary service, it is incumbent upon policy makers and educationalists concerned with young people's preparation for civic participation to take the full range of citizenship acts into account. 


\section{THE RISE OF A NEO-COMMUNITARIAN PROJECT: A CRITICAL YOUTH WORK STUDY INTO THE PEDAGOGY OF THE NATIONAL CITIZEN SERVICE IN ENGLAND}

\section{Digital natives: political and social activism}

It seems clear that young people in the 21 st century should be recognised as a diverse and heterogeneous social group with social awareness, political understanding and increasingly global identities. As Wyn and White (1997) argue, social scientists should view young people's lives through a prism, thereby offering a perspective which provides for multiple possibilities and counter-narratives about what it means to be young. Also, Mayo et al. (2009) recognise a growing interest to conceptualise citizenship in much broader terms, and ways which explore the connections between the local, the national and global dimension. According to Birdwell \& Bani (2014), we are witnessing the first generation of 'digital natives', to describe today's youth whose engagement with social media and new technologies have transformed their identities and world-view. There is growing evidence to show that young people are digitally and politically engaged, using social media to express opinions e.g. Twitter debates \#euromaidan (Barberá and Metzger, 2014). Moreover, Digital Democracy Commission (2015) acknowledged that rather than being apathetic, many young people were interested in political issues, and actively involved with local, civic and community initiatives. Also, in terms of volunteering, young people have the highest participation rate for any age group (Cabinet Office, 2016).

A concern here is that the NCS offers an approach to citizenship which is predicated on a prescriptive definition of social action, with limited scope for agency and selfdetermination. Gordon and Taft (2011) use the term of 'adultism' to describe young people's sense of powerlessness and discrimination in adult-led social action projects. Similarly, Kennelly (2011) refers to the idea of 'relational agency' to contextualise young people's limited power to shape social change, especially when participating in youth political activism, e.g. 2010 protests against increases in university tuition fees. Therefore, it seems possible to conclude that increasingly young people desire a political system which can 


\section{THE RISE OF A NEO-COMMUNITARIAN PROJECT: A CRITICAL YOUTH WORK STUDY INTO THE PEDAGOGY OF THE NATIONAL CITIZEN SERVICE IN ENGLAND}

engage them in the present and if they are afforded the right opportunities, and support, they might be able to transform our expectations and notions of active citizenship.

\section{Neo-communitarian model: marketisation of youth provision}

There is emerging evidence which indicates that the NCS commissioning of youth provision, what can be termed neo-communitarism, plays a key role in reconfiguring service delivery and impacts on young people's entitlements. Mason (2015) defines these changes as a form of 'austerity youth policy' which is characterised by the process of 'marketisation and privatisation' and concludes that 'the neoliberal project has significantly compromised the character and stability of open-access youth work' (2015, p56). Also, young people's disillusionment with politicians is exacerbated as the most recent socio-economic research suggests the Government's austerity measures have a disproportionate impact on young people (Hills et al., 2015). It is argued that the Government allocation of $£ 900$ billion over the next four years to expand the NCS is compounding the problem. The new funding is in stark contrast to the ongoing austerity measures, with local authority youth services being most adversely affected. Since April 2010, funding cuts to youth service amounts to $£ 387 \mathrm{~m}$ (UNISON, 2015), and similar financial impacts are being replicated in the voluntary and community youth sector with around $£ 1.7$ billion reduction in grants (NCVYO, 2013, online).

The proposed expansion of the NCS, through the commissioning and tendering of services, is creating a market of new youth providers. It is indicative of a youth policy which seeks to construct a youth sector based upon a 'payments-by results' delivery model. Cooper (2012) suggests that the current national youth policy framework is 'closing off opportunities for progressive ways of working with young people' (2012, p6). The concern about a neocommunitarian approach is that it fosters compliance with a form of practice which offers 


\section{THE RISE OF A NEO-COMMUNITARIAN PROJECT: A CRITICAL YOUTH WORK STUDY INTO THE PEDAGOGY OF THE NATIONAL CITIZEN SERVICE IN ENGLAND}

little scope for critical thinking and enquiry about existing power relations and structural inequalities.

The recent NCS commissioning process indicates that this neo-communitarian trend has been accelerated and is indicative of how neo-liberalism and market logics have encroached into the social action field. There is evidence to suggest that the marketisation process conflates youth volunteering with employability, as we witness the prominence of commissioned providers with an expertise in delivering employability skills and Welfare to Work programmes. For instance, Seetec, aims to empower people 'to gain the skills and attributes to secure and sustain employment' (Seetec, 2016, online); and Ingeus Ltd purports a citizenship vision 'founded on the core belief that work is good for the individual, good for the economy and good for society' (Ingenus, 2016, online).

The new neo-communitarian approach is based on quantitative metrics (Kirkman et al., 2016) using targeted youth interventions with quantifiable social impact as the measures of success. The 'invest to save' model is based on US civic action programmes such AmeriCorps and it is suggested that the NCS and other social action programmes can demonstrate social value and 'generate significant returns on investment in the medium to long term' (Birdwell, et al., 2015, p51). Moreover, the manifestation of the neocommunitarian approach is now evident within English youth services, as local authorities increasingly look towards 'invest to save' solutions to address funding cuts, an recent example is Epic CIC commissioned to run a London borough youth service (Jozwiak, 2017).

\section{The research study}

The study focuses on making sense of the youth citizenship theory, policy and practice from a critical practitioner-researcher perspective. It sees knowledge generation as dynamic, changing and inter-disciplinary, and sense making is considered an interpretation of 


\section{THE RISE OF A NEO-COMMUNITARIAN PROJECT: A CRITICAL YOUTH WORK STUDY INTO THE PEDAGOGY OF THE NATIONAL CITIZEN SERVICE IN ENGLAND}

multiple realities, similar to the notion 'bricolage' (Kincheloe and Mclaren, 2008) or 'fissures' (Siverman, 2011), i.e. a collection of the fractured or partial accounts of social reality. Within the educational research field, the approach could be termed 'meaningful praxis', used to bridge the divide between academic and practice (Kemmis, 2012, 2010). It acknowledges the importance of positionality and reflexivity (Gormally and Coburn, 2014; Etherington, 2007) in creating an 'arena for dialogue' (Freire, 1972), enabling self-reflexivity amongst interview subjects, capturing experiences, and the possibility to theorise about our social realities.

\section{Research participants}

Purposive sampling was used to recruit a total of 10 participants; it was based upon the judgement of the researcher, with the intention to select a group of experienced and knowledgeable professional practitioners. The gender ratio was equally balanced; and the ethnicity (self-defined) consisted: White British $(n=7)$, British Pakistani $(\mathrm{n}=1)$, and 2 African $(n=2)$, considered as reflective of the North East of England practitioner population. The cohort consisted of a diverse range of practice roles including: Manager $(n=2)$, full-time Youth Worker $(n=7)$, and Youth Support Worker $(n=1)$. The entire cohort consisted of nationally qualified JNC youth and community professionals, with several years of post qualification experience, including: $11+$ years $(n=1), 5-10$ years $(n=4), 2-5$ years $(n=2)$ and Less than 2 years $(n=3)$. There practice experience and knowledge, including working across a diverse range contexts, such as statutory, voluntary and community, citizenship projects, volunteering projects, and not-for-profit/community interest. The range of curriculum knowledge included: youth forums, youth parliament, peer mentoring, youth volunteering, youth community action, youth surveys, youth campaigns and youth websites/blogs. 


\section{THE RISE OF A NEO-COMMUNITARIAN PROJECT: A CRITICAL YOUTH WORK STUDY INTO THE PEDAGOGY OF THE NATIONAL CITIZEN SERVICE IN ENGLAND}

\section{Interview method}

The data collection method used was in-depth qualitative interviews. The interviews lasted between 45-55 minutes in duration, conducted in familiar and comfortable environments negotiated between researcher and participant. The interviews took place over a sixth month period in 2015 and generated 7 hours 44 minutes of primary data. Each interview was recorded and transcribed verbatim and each participant was assigned a number, thereby ensuring anonymity, as no personal or identifying information was reflected in the transcripts.

Each participant was given a copy of the interview questions to enable an overview of the discussion threads and participants were encouraged to seek clarification or raise other points of interest considered useful to the study. Initial questions were open-ended to allow each participant to share his or her own experiences and perspectives without being affected by possible biases. After the initial responses, the researchers used follow-up questions intended to illicit further detail and clarify meaning. The semi-structured interview questions used were: 1) What does the term citizenship mean for young people?; 2) What types of things should they learn about citizenship?; 3) In what ways do young people demonstrate their citizenship?; 4) What do you think citizenship projects like NCS are trying to achieve?; 5) Describe for me the 'type of citizen' that the NCS is trying to encourage?; 6) Can you suggest how other youth projects are developing citizenship work with young people?; 7) In what ways do these differ from the NCS?, and why is this do you think?

\section{Data analysis}

All interviews were recorded and transcribed verbatim to electronic files. Transcripts were analysed using an iterative process involving coding of all transcripts, note taking around initial findings, before identifying emergent themes. The initial findings from the analysis were presented to the interviewees for comment and review, ensuring authenticity of 


\section{THE RISE OF A NEO-COMMUNITARIAN PROJECT: A CRITICAL YOUTH WORK STUDY INTO THE PEDAGOGY OF THE NATIONAL CITIZEN SERVICE IN ENGLAND}

the accounts and validity of the understanding and assumptions (Etherington, 2007; Kemmis, 2010). Following the initial review, additional categories were developed and all transcripts that were previously coded were revisited and updated using the new coding theme list.

\section{Research Findings}

In presenting the findings, extracts are taken from the interviews to provide supporting evidence for the interpretations. The themes are linked in this discussion to provide a detailed explanation of how the concept of citizenship is contested in practice, with different professionals recognising how their values and principles shape their understanding. Importantly, the context for practice is indicated as a key factor in informing the assumptions about the effectiveness of practice interventions. From the analysis, four salient themes emerge, which are categorised: a) Citizenship status as 'economic imperative'; b) Reconfigured youth interventions; c) Social construct of a 'good citizen'; and d) Limited youth social and political social agency. The final part of the section considers the theoretical implications, and suggests how policy makers and service providers can better support young people in developing their sense of citizenship.

\section{a) Citizenship status as 'economic imperative'}

A dominant theme throughout the discussions with youth work professionals was the emphasis that young people participating in the NCS programme placed on the importance of 'CV building' as an opportunity to enhance employment and university applications. As one NCS Team Leader stated:

Those joining the Spring and Autumn programmes do tend to be college students that are switched on, they know what they're doing and it's about a CV for them. 
These descriptions are indicative of the manner by which the NCS conflates the idea of 'rites of passage' with employability skills. As Youth Support Worker explained:

I work a lot in colleges and we see the NCS recruiting in the colleges, so again they recruiting the type of young people who are already motivated and got aspirations to go to college. We don't see any NCS people coming here on our estate to recruit our young people who maybes don't go to college.

There were similar views about the emphasis placed on employability, in particular regarding the methods used to recruit NCS participants from the local youth project and communities. A Youth Work Manager stated that:

The typical young person who does NCS for me, are those young people who I have worked with who get involved in absolutely everything. If I say I have a peer-mentoring course, they are the first ones to sign up, and the first ones to be involved. They want it on their CV they want it to better themselves. I do not think that other young people would get involved in NCS I think you have to be that type of person.

Interestingly, the research indicated that the practitioner's perception of the young person's motivation and perceived needs influenced how they considered their role. As an NCS youth worker highlighted:

I think many young people that come in say are NEET, they want CVs and job applications. We do that and help these young people, whereas other young people would do that for themselves naturally. So for those types of young people that come in they are demonstrating that yes I do want to work, help me get a job.

Another practitioner, with previous experience of working with young people on the NCS, suggested that at times the mentality of the citizenship programme was designed to "fix" young people, in particular whilst engaging with 'hard to reach' categories. As a Youth Worker suggested:

In most cases the young people that we worked with on the NCS were "hard to reach" ... at times it seemed like you only see their faults, as if we are going to fix them... the NCS programme will "fix them". But you also need to see what they have done. So I think sometimes you don't see what they have actually done, you work with them but you don't see how they contribute to society or the community they are living in.

\section{b) Reconfigured youth support and interventions}




\section{THE RISE OF A NEO-COMMUNITARIAN PROJECT: A CRITICAL YOUTH WORK STUDY INTO THE PEDAGOGY OF THE NATIONAL CITIZEN SERVICE IN ENGLAND}

The discussion revealed the work of the NCS had led to some changes in the emphasis and the nature of youth provision. The findings indicate that the short-term and intensive nature of the programme was problematic in terms of young people's development needs and ongoing support. As a Youth Worker stated:

Youth work is about relationships isn't it, and the trust of the young people you know; working for the young people. If you just come in for a two week project then off you go again, it's not youth work.

Also, practitioners raised some questions about the approach of the citizenship programme. In particular, recognising that the development of trust and sustaining relationships with young people over time. Such an approach was considered a key element of effective practice in supporting young people's awareness and development of citizenship. An experienced Youth Work Manager stated:

We have had it when they came and recruited from us, so we got young people involved, it was very much they've gone and done that. They come back to the youth project and you know, we are still here for them I think their needs to be another agency doing follow up work, you've done NCS what came from it? What have you learnt? I think if they haven't got a youth project they've just got a certificate to say they've took part, great, what actually have you got from it though?

In addition, the research indicated that some practitioners were critical of the NCS citizenship programme because it provided insufficient time to build relationships or support young people in a meaningful way. Concerns about the nature of relationship and intensity of the NCS programme, in particular the half-term programmes. As a Youth Support Worker indicated:

It's a quick fix, I don't think the staff on NCS have time to build relationships with young people, so you wouldn't get to find out any needs they have; it's a very quick fix a two week programme. In a half term you're not gonna get to know young people, you're not gonna find out what issues they got, for me it's a quick fix, look at me I've got a certificate. I am youth worker I build relationships up with young people so that they can come and tell me things; you haven't got time to do that on NCS. It's a tick box exercise.

An experienced youth worker, and former NCS youth worker, reflecting on their early NCS project work experience stated: 
THE RISE OF A NEO-COMMUNITARIAN PROJECT: A CRITICAL YOUTH WORK STUDY INTO THE PEDAGOGY OF THE NATIONAL CITIZEN SERVICE IN ENGLAND

For me, from my personal experiences of doing youth work is difficult, especially in the first year of NCS. I was doing a lot more hours than I even thought. You get a paper giving you all these things about a young person, and when you start talking to them you realise they have got other issues; things that were nothing to do with the volunteering work. But of course you have to deal with them ... it almost like a ticky-box job, you find yourself to be ticking everything. But you don't have the money; you don't have the time as well because it's so very, very structured.

Other practitioners, recognising the amount of effort and time taken to develop a positive relationship and shared a sense of frustration arising from practice because the programme is time limited. An NCS project worker commented that:

... and then they go and that's sad, cos you have built a relationship and you would wanna keep that relationship just to find out what they've done, but you can't it just like you've contributed to someone growth and that's it bye bye and then they go and that's it.

Moreover, the research indicated that the acquisition of citizenship skills and knowledge

within the NCS programme was based on a staged approach to learning as representing a form of 'focused youth work'. As NCS Team Leader explained:

I think at the minute the biggest thing about the NCS is in the way that it is organised and structured. What works is it's a young person led programme that from start to finish, they put their stamp on it, it's their local community, and they make the difference. They want to be involved in to but you can't say its youth work. It is very much focused youth work, they have a set agenda, this is what we are gonna do: community project, we gonna do a residential.

The structured approach to learning and participation was also evident in the pedagogy of the NCS and the assumption about how young people need to learn about citizenship. It suggested an incremental and staged approach, as an NCS youth worker stated:

I think before they can understand citizenship in the wider community they definitely need to focus on their local community to start with and slowly graduate their way up as they work their way through education - start local community move on to next transition and you start to broaden your horizons. I think they need to learn about where they are, in terms of their community, what part and role they play and how they can help it, like.

\section{c) Social construct of a 'good citizen'}

The discussions illustrated how different practitioner's concept of citizenship informed and shaped the expectation of young people. The findings indicated that whilst there are some 


\section{THE RISE OF A NEO-COMMUNITARIAN PROJECT: A CRITICAL YOUTH WORK STUDY INTO THE PEDAGOGY OF THE NATIONAL CITIZEN SERVICE IN ENGLAND}

common aspects, no one defined type of citizen emerged, therefore it suggests that definitions and constructs of a 'good citizen' can be categorised as mixed rather than fixed. A NCS youth worker explained:

I see it playing a role as an active citizens in modern society now, of helping other in the community in some shape or form and being a active role in participating in different sort of things that are going on amongst us. I think as well a part of being an active citizen is like helping to shape what the community is about and like being involved in different groups to say what they want in the areas and how they can benefit in some form

Interestingly, what emerges from the research is as an understanding about moral imperatives and duties associated with citizenship status, but importantly, there was an acknowledgement that most young people already possess these qualities. A VCS Youth Work Manager indicated:

It's really about civic duties, living within the rules of the land; respect and tolerance; helping people to have their own opinion - these are the key values. I would say that a lot of young people already know about those duties and that anyway. What doesn't exist is a forum where they can take those discussions further. I think if you pick any young person of the street and ask them: What is a good citizen? I think that most people would be able to come up with something that is agreeable.

Importantly, within the data further counter-narratives emerged which challenged the 'deficit model' of youth, and contested the idea that young people are self-serving. In particular the findings indicated that young people are recognised as already demonstrating social responsibility with regards to family obligations, and other duties. As a Youth Worker manager stated:

I think everyone is a citizen. I don't think you should go around demonstrating it. If you've got something you feel strongly about so if you are involved in youth parliament, you feel strongly you are going be involved in different aspects maybe more than somebody who is NEET, but just because they're are NEET doesn't mean that they are good citizens. I think, a lot of other young people take care of other siblings, you know they're often in charge and can't come tonight cos they have to look after so and so, is a responsibility, they think of it as babysitting.

There was also recognition that young people already exhibit positive behaviour and show a commitment to self-development within their everyday lives. The Youth Support Worker confirmed: 


\section{THE RISE OF A NEO-COMMUNITARIAN PROJECT: A CRITICAL YOUTH WORK STUDY INTO THE PEDAGOGY OF THE NATIONAL CITIZEN SERVICE IN ENGLAND}

Most young people attend school, get their exams, maybe not going to college, but looking to want to get a job, they take part in youth projects, we've got peer mentors, and have run a youth board of management and youth forums over the years'

Also the discussions indicated that young people are already actively engaged and participate as a regular sports and leisure activities, a Youth Worker stated:

They are being responsible, they're in football teams, they're in rugby teams, they're part of things, they belong to the youth club, and they belong to the rugby team.

Similarly, their social responsibility is exhibited and fostered within faith-based and cultural activities, and family life. The VCS manager stated:

If you look at from a faith perspective, there are a lot of things that happen in mosques or churches, promoting what's happening, collections ... even to thinks that when they learn prayers or Arabic they have a duty to do things; and even within a family you have a duty to look after each other

\section{d) Limited youth social and political social agency}

The research findings indicated that the NCS social action projects provided some opportunities for more challenging examples of community action. These included a range of social and cultural awareness campaigns, which one as an NCS Team leader described as a 'original' and 'dangerous' project

One group did a community safety with the car crash, which was originally considered as a "dangerous project". But because of how fresh it was, we like the idea of raising awareness about community safety. But the NCS panel initially rejected it because of the time structures and because it was so fresh. However, they came back within a month and it was accepted straight away ... and they are just at the critical end of it and getting their DVD put in place.

There was also an example of cultural awareness campaigns. As a Youth Worker explained:

... it was around the time of Eid, so they did a research, cos a lot of people from the Asian backgrounds have high cholesterol, and as they were fasting there is a tendency to break the fast by eating a lot of junk food. So we did like a radio phone-in sessions to raise awareness, young people were involved in chatting to people that phoned in, giving them more information about of how to break the fast with healthy options and gradually introducing food into your body.

However, the findings indicated that the NCS was considered as such form of citizenship practice which could be described as less transformative than youth work. It was suggested 


\section{THE RISE OF A NEO-COMMUNITARIAN PROJECT: A CRITICAL YOUTH WORK STUDY INTO THE PEDAGOGY OF THE NATIONAL CITIZEN SERVICE IN ENGLAND}

that the social action projects tended to focus on awareness-raising rather than critical thinking or challenging social injustices and inequality. As a Youth Worker suggested:

I think it is very structured rather than say a youth club session where you would just be sitting, being able to chat and projects would naturally developed from what you talk about with young people and do a piece of work around that. I think the NCS is very much focused without much room for manoeuvre, if they were coming out with racism, for example, I don't know if NCS would have the time to work around that or to stick to the schedule.

When asked how they would address issues such as racism in a community within a project,

an NCS youth worker explained:

That's a difficult one to put into social action, social action isn't about social change. There are projects that have been done around raising awareness. For dealing with racism, the example you use, I have never come across it yet, if came up I sure a team would look at tackling it. If a team came up with a campaign to raise awareness about it, a family fun day about community mix, rather that tackling the issue straight on.

Therefore, the complexity of some issues may conflict with the time limits of the social

action work. A NCS Team Leader when asked about tackling racism or sexism stated:

I think that for the sort of projects that are gonna be difficult to achieve in the deadline, but we normally have teams that go on from the original idea, to do a graduate project afterwards. They have got a bit more leeway and don't necessarily have as much of a deadline to that one done.

The findings also provided some evidence that many of the young people participating in the NCS schemes were already involved in volunteering opportunities; bringing with them key skills such as team-working and inter-personal skills. A NCS worker stated:

We get loads come in saying that they haven't done any volunteering work, oh I did a weekend away with the scouts, you say that voluntary work ... they say oh I didn't know that.

Other examples mentioned, as an NCS Team leader mentioned:

We find that quite a lot of sign ups coming from Cadets, Police Cadets we get a lot of that; we got involved in a community skate park; we work with a disabled arts group ... so many young people come in with all these links and able to help the rest of the group, coming up with ideas and getting them into volunteering as well. 


\section{THE RISE OF A NEO-COMMUNITARIAN PROJECT: A CRITICAL YOUTH WORK STUDY INTO THE PEDAGOGY OF THE NATIONAL CITIZEN SERVICE IN ENGLAND}

Importantly, the findings illustrated how young people should be recognised as active citizens in their own right as they already demonstrate a commitment to positive social action within their everyday lives. Such examples provide a counter claims to the often negative perception of young people as disengaged and anti-social. As a Youth Work Manager suggested:

I think there are a lot of young people that are doing things that possible don't get recognised, if you look at the Scouts, the Guides, Sunday League football. There are groups of young people that get involved and volunteer, help out; do a whole hoard of different things without necessarily under a badge of citizenship.

Also, the findings indicate that young people are already showing their commitment to their communities, their families and their own futures. As a Youth Support Worker said:

Most young people attend school, get there exams, maybe not going to college, but looking to want to get a job and take parts in youth projects. We've got peer mentors, youth board of management, and different youth forums over the years. Young people will get involved in it, if you can put it across in way that they can they get excited about it, fabulous, they get involved without even realising, so young people show good citizenship without realising it themselves.

\section{Discussion}

Recent research findings suggests that the commissioning of NCS services has led to a significant change in the priorities of social action provision, in a manner which undermines youth rights and is detrimental to the idea of universal service entitlement. Therefore, as a neo-communitarian model, social action has become based on based on a normative idea of social justice which emphasises individual responsibility and self-responsibility (Sinclair, 2010); as such the social rights of citizenship are contingent upon achieving successful transitions into paid work. As such it is emblematic of the 'new outcome-focused and curriculum-led culture' (Smith, 1988, p5) which have refashioned youth provision in the $21^{\text {st }}$ century. 


\section{THE RISE OF A NEO-COMMUNITARIAN PROJECT: A CRITICAL YOUTH WORK STUDY INTO THE PEDAGOGY OF THE NATIONAL CITIZEN SERVICE IN ENGLAND}

The research indicates that citizenship is considered as part of the everyday language of youth and community work practice, and as such, it was an integral part of good youth work practice. The assumptions is that certain forms practice have a moral legitimacy, which can be argued is based on critical reflection on practice, and possess what Dewey (1938) termed 'cumulative instrumental' value, as judgements based on the application of competency. The reasoned judgement implied here is that effective practice is based on sustained relationships with young people, and it was evident that youth workers regretted the omission of sustainability within their practice in the NCS social action teams. Moreover, several practitioners were critical of the time-bound and structured nature of the NCS programme, categorised as a 'quick fix' or 'tick-box' type of citizenship devoid of any meaningful form of criticality.

\section{Figure 1: A model for neo-communitarian citizenship}

\section{Pedagogy:}

- Neo-liberal philosophy

- Communitarian philosophy

- Citizenship as an 'economic imperative'

- Individual rational choice/action

\section{Process of change:}

- Notion of 'rites of passage'

- New social/market enterprise

- Targeted service provision

- Social impact i.e. payment by results

\section{Curriculum:}

- Deficit model of youth

- Set of structured communal tasks

- Limited political agency

- New civic activism

\section{Desired outcome:}

- Culture of civic volunteerism

- Socially responsible generation

- Employability skills i.e. work ready generation

- Youth positivism i.e. giving back to society 


\section{THE RISE OF A NEO-COMMUNITARIAN PROJECT: A CRITICAL YOUTH WORK STUDY INTO THE PEDAGOGY OF THE NATIONAL CITIZEN SERVICE IN ENGLAND}

There is evidence to show that the introduction of the NCS has led to a new market for youth service providers which have resulted in spaces for critical youth work practice becoming more problematic (Cooper, 2012). In the context of the current political and economic climate it can be argued that the NCS has nurtured a form of youth work practice which 'imposes constraints and raises contradictions; complicating the delivery of services, at the same time as diminishing the rewards of inspired practice at all levels' (Mason, 2015, p19). Here, the research findings offer some useful insights into the NCS curriculum; it illustrated that practitioner had identified that participants perceived that engaging with the NCS project would contribute towards their CV-building (de St Croix, 2011). Moreover, it provides some evidence that NCS conflates the notion of 'rites of passage' with employability skills as part of successful transitions into adulthood (Bacons, et al., 2013), and refers to youth as 'assets' and 'resources' within a productive economy and society (Barber, 2009; Biesta et al. 2009; Bagnall, 2010; Davies, 2013).

The research findings indicate that practitioners recognised the importance of young people's participation in local community action, which concord with the values of a civic communitarian approach. There is clear evidence that the NCS makes a significant contribution towards young people's civic engagement through social action projects, including some more challenging examples such as awareness raising activities. However, it is evident that the NCS represents a volunteering programme which makes a distinction between civic and political realms of citizenship. For whilst the research illustrated that the NCS programme afforded young people the opportunity participate in pro-social civic action, e.g. planting communal gardens, there was less evidence of how the NCS facilitated young people's engagement in more controversial aspects of their lives, e.g. dealing with racism. There were a few some examples, e.g. awareness about healthy eating during Ramadan, 


\section{THE RISE OF A NEO-COMMUNITARIAN PROJECT: A CRITICAL YOUTH WORK STUDY INTO THE PEDAGOGY OF THE NATIONAL CITIZEN SERVICE IN ENGLAND}

however, the message from practitioners suggested the initial six week programme was not designed accommodate the more challenging issues affecting young people.

Importantly, the research highlighted that practitioners have a more nuanced understanding of youth that provides for multiple possibilities and counter-narratives about what it means to be young (Wyn and White, 1997). The research findings indicated that practitioner's notion of the 'good citizen' was considered as mixed rather than fixed, reflective of the idea of citizenship as a continuum (Westheimer and Kahne, 2004) thus offering the possibility to incorporate both realms of civic and political citizenship acts. As the findings show, young people routinely demonstrated social responsibility within their everyday lives, e.g. doing part-time work, attending school, sitting exams, as well as caring responsibilities in families. It therefore offers the possibility to conceptualise citizenship, as Mayo et al., (2009) suggest in much broader terms, and ways which explore the connections between the personal, cultural and global dimensions.

The research generated some critical insights into the social impact and transformative nature of the social action work, and here the evidence suggests that the NCS fails to effectively address the challenging and difficult aspects of young people's experiences. For instance, the notion that 'social action isn't about social change' can be considered as indicative of a programme which has a very uncritical understanding of supporting young people, and raises questions about how far the work can be considered as transformative or seeks to support young people to confront prejudices and injustice.

As these findings concord with recent NCS research studies (Murphy, 2014, Bacon, 2013, de St Croix, 2011) which demonstrate that the Government rhetoric on citizenship across England implies that young people's entitlement to citizenship is predicated, not so much on their knowledge of political systems and voting rights, but instead, in civic acts such as volunteering, self-restraint and duty to others. Therefore, if there is a genuine desire to 
THE RISE OF A NEO-COMMUNITARIAN PROJECT: A CRITICAL YOUTH WORK STUDY INTO THE PEDAGOGY OF THE NATIONAL CITIZEN SERVICE IN ENGLAND

empower young people to shape their lives in the $21^{\text {st }}$ century, policy makers, educationalists and researchers need to adopt a more nuanced understanding of citizenship. It needs to be acknowledged that young people already possess the competency to identify solutions to local issues, if only adults would take the time to listen. A useful starting place would be to recognise that the emergent neo-communitarian ethos of the National Citizen Service programme is problematic for young people, practice and wider society.

\section{References}

Bacon, K., Frankel, S. and Faulks, K. 2013. "Building the Big Society: Exploring representations of young people and citizenship in the National Citizen Service" The International Journal of Children's Rights 21(3): 488-509.

Barber, T. 2009. "Participation, citizenship, and well-being: Engaging with young people, making a difference" Young 17(1): 25-40.

Bagnall, R. 2010. "Citizenship and belonging as a moral imperative for lifelong learning" International Journal of Lifelong Education 29(4): 449-460.

Barberá P and Metzger, M. 2014. Tweeting the Revolution: Social Media Use and the Euromaidan Protests [Online] available at: http://www.huffingtonpost.com/pablo barbera/tweeting-the-revolutions_b_4831104.html?utm_hp_ref=tw accessed 21.02.16.

Biesta, G., Lawy, R. and Kelly, N. 2009. "Understanding young people's citizenship learning in everyday life: The role of contexts, relationships and dispositions" Education, Citizenship and Social Justice 4(1): 5-24.

Birdwell, J. \& Bani, M. 2014. Introducing Generation Citizen London: Demos.

Birdwell, J., Scott, R. and Reynolds, L. 2015. Service Nation 2020 London: Demos.

Blond, P. 2010. Red Tory: How the Left and Right Have Broken Britain and how we can fix it, London: Faber \& Faber.

Blunkett, D. 2003. Towards a Civil Society, London: Institute for Public Policy Research.

Cabinet Office, 2016. Community Life Survey 2015-16. [Online] Available online: https://www.gov.uk/government/publications/community-life-survey-2015-to-2016-data Accessed 19.02.17 


\section{THE RISE OF A NEO-COMMUNITARIAN PROJECT: A CRITICAL YOUTH WORK STUDY INTO THE PEDAGOGY OF THE NATIONAL CITIZEN SERVICE IN ENGLAND}

Cooper, C. (2012) 'Imagining 'radical' youth work possibilities - challenging the 'symbolic violence' within the mainstream tradition in contemporary state-led youth work practice in England" Journal of Youth Studies 15(1): 53-71.

de St Croix, T. (2011) "Struggles and silences: Policy, Youth Work and the National Citizen Service” Youth \& Policy No. 106 May 201

Davies, B. 2013. "Youth work in a changing policy landscape: the view from England" Youth \& Policy No. 110 May 2013.

Dewey, J. 1938. Logic: the Theory of Inquiry. Holt, Rinehart and Winston

Etherington, K. 2007. "Ethical Research in Reflexive Relationships" Qualitative Inquiry 13(5): 599-616.

Etzioni, A. 1995. The Spirit of Community: Rights, Responsibilities and the Communitarian Agenda, London: Fontana.

France, A. 2007. Understanding youth in late modernity, Maidenhead: Open University Press.

Freire, P. 1972. Cultural Action for Freedom, Middlesex: Penguin Education.

Furlong, A. 2013. Youth Studies: An Introduction, London: Routledge.

Glasman, M. 2010. "Society not State: The challenge of the Big Society" Public Policy Research 17(2): 59-63.

Gormally, S. and Coburn, A. 2014. "Finding Nexus: connecting youth work and research practices" British Educational Research Journal 40(5): 869-885.

Hart, S. 2009. "The 'problem' with youth: Young people, citizenship and the community" Citizenship Studies 13(6): 641-657.

Hills, J., Cunliffe, J., Obolenskaya, P. and Karagiannaki, E. 2015. Falling Behind, Getting Ahead: The Changing Structure of Inequality in the UK, 2007-2013 Summary Research Report 5, LSE, Centre for Analysis of Social Exclusions (CASE).

House of Commons, 2017 Committee of Public Accounts: National Citizen Service: Fortysixth Report of Session 2016-17 London: House of Commons. 
Hurd, N. (2012) 'National Citizen Service is a flagship initiative supporting the government's vision for building the Big Society' [Online] available at: https://www.gov.uk/government/news/national-citizen-service accessed 24.02.17.

Ingenus. 2016. About Us [Online] available at: http://www.ingeus.co.uk/about/about-us, 70 accessed 08.02.16.

Jozwiak, G. (2017) "NCS programmes may lose money, research suggests" Children and Young People Now 09 March 2017 [Online] available at: http://www.cypnow.co.uk/cyp/news/2003306/ncs-programmes-may-lose-money-researchsuggests accessed 20.03.17.

Kemmis, S. 2010 "Research for praxis: knowing doing" Pedagogy, Culture \& Society 18(1): 9-27.

Kemmis, S. 2012. "Researching educational praxis: spectator and participant perspectives" British Educational Research Journal 38(6): 885-905.

Kennelly, J. 2011. Citizen Youth: Culture, Activism, and Agency in a Neoliberal Era London, UK: Palgrave Macmillan.

Kincheloe, J. L. and McLaren, P. 2008. "Rethinking Theory and Research", in Denzin, N.K. and Lincoln, Y. The Landscape Of Qualitative Research. 3rd edn. London: Sage.

Kirkman, E., Sanders, M., Emanuel, N. and Larkin, C. 2016. Does Participating in Social Action Boosts the Skills Young People Need to Succeed in Adult Life? Behavioural Insights Team/Cabinet Office [Online] available at:

http://www.behaviouralinsights.co.uk/publications/evaluating-youth-social-action-finalreport/ accessed 08.02.16.

Mason, W. 2015. “Austerity youth policy: exploring the distinctions between youth work in principle and youth work in practice" Youth \& Policy 114: 55-74.

Mayo, M., Gaventa, J. and Rooke, A. 2009. "Learning global citizenship? Exploring connections between the local and the global" Education, Citizenship and Social Justice 4(2): $161-175$.

Murphy, S. F. 2014. "Bordered citizenship: National identities, transnational lives and the limitation of the UK's National Citizen Service" Youth Voice Journal [Online] available at: http://youthvoicejournal.com/2014/04/17/sean-f-murphy-2014-bordered-citizenship-nationalidentities-transnational-lives-and-the-limitation-of-the-uks-national-citizen-service/.

National Audit Office. 2017. National Citizen Service. London: National Audit Office. 


\section{THE RISE OF A NEO-COMMUNITARIAN PROJECT: A CRITICAL YOUTH WORK STUDY INTO THE PEDAGOGY OF THE NATIONAL CITIZEN SERVICE IN ENGLAND}

NCVYO. 2013. Local authority expenditure on Children and Young People's Services NCVYO [Online] available at: http://ncvyspolicy.wordpress.com/ accessed 12.04.15.

Oldfield, A. 1990. Citizenship and Community: Civic Republicanism and the Modern World. London: Routledge.

Putnam, R. 2000. Bowling alone: The collapse and revival of American community. New York: Simon and Schuster.

Russell, I. 2005. A National Framework for Youth Action and Engagement Norwich: HMSO.

Sandel, M. 1996. Democracy's Discontent: America in Search of a Public Philosophy Cambridge: Harvard University Press.

Seetec. 2016. Values and Policy [Online] available at: http://www.seetec.co.uk/about/valuesand-policy accessed 08.02.16.

Silverman, D. ed. 2011. Qualitative Research: Issues of Theory, Methods and Practice. 3rd edn. London: Sage.

Sinclair, S., McKendrick J. H. and Scott G. 2010. "Failing young people? Education and aspirations in a deprived community" Education, Citizenship and Social Justice 5(1): 5-20.

Smith, M. K. 1988. Developing Youth Work: Informal Education, Mutual Aid and Popular Practice, Milton Keynes: Open University Press.

Gordon, H. and Taft, J. 2011 "Rethinking Youth Political Socialization: Teenage Activists Talk Back" Youth \& Society 43(4): 1499-1527.

UNISON. nd. The UK's youth services how cuts are removing opportunities for young people and damaging their lives [Online] available at:

https://www.unison.org.uk/upload/sharepoint/On line Catalogue/22532.pdf accessed 10.06.15.

Westheimer, J. and Kahne, J. 2004. "What kind of citizen? The politics of educating for Democracy" American Educational Research Journal 41(2): 237-69.

Wyn, J. and White, R. 1997. Rethinking Youth. Sydney: Allen and Unwin.

Youniss, J., Bales, S., Christmas-Best, V., Diversi, M., McLaughlin, M. and Silbereisen, R. 2012. "Youth Civic Engagement in the Twenty-First Century" Journal of Research on Adolescence 12(1): 121-148 